\title{
Effects of Composite Material Layers on the Mechanical Properties for Partial Foot Prosthetic Socket
}

\author{
S. M. Abbas \\ P\&O Eng. Dep \\ Al-Nahrain University, Baghdad, IRAQ \\ saifmohammad645@yahoo.com \\ Received: 12-Oct.-2017 Revised: 15-Nov.-2017 Accepted: 18-Jan.-2018 \\ http://doi.org/10.29194/NJES21020253
}

\begin{abstract}
In this work, nine types of laminated composite materials used for experimental study to investigate the tensile and fatigue properties of partial foot prosthetic socket which fabricated by using vacuum pressure system . The composite material matrix were Lamination 80:20and reinforced with nine types of laminations (perlon, n-glass, fiber glass and carbon) by variation of thickness according to lamination. Results show that the mechanical properties were improved by increasing the two layers of carbon fiber, fiber glass and n-glass layers instead of zero layer with six layers of perlon lead to the increased in(yield strength $\boldsymbol{\sigma y}$, ultimate tensile strength $\boldsymbol{\sigma}$ ult and modules of elasticity $\mathrm{E}$ with $(71 \%, 76 \%$ and $58 \%$ ) respectively for carbon fiber, (20\% , 19\% and $40 \%$ ) for fiber glass and ( $22 \%, 5.5 \%$ and $29 \%$ ) for n-glass. Results show that (3perlon+2carbon fiber+3perlon) gives the best value of mechanical properties and has higher Endurance limit stresses (бe) which increase lifetime for the patient. It is recommend to use this type of lamination for the layup partial foot prosthetic socket because it meets the demand lamination layers for acceptable mechanical properties and its minimizing the cost of socket lamination to suitable costing value.
\end{abstract}

Keywords: Partial Foot Socket, Tensile, Fatigue, Laminated Composites.

\section{Introduction}

Prosthetic limbs are artificial devices which substitutes missing body parts (limbs) of the amputee. A person may face amputation due to disease or accidents. The amputee's limbs are hence replaced by prosthetic limbs which are designed to meet the performance level of natural human limbs equally providing comfort to the amputee. Prosthetic limbs allow amputees to continue their day to day life. Lower extremity prosthesis provides replacement of lower limbs at varying levels of amputation. Prosthetic foot helps the amputee to walk independently adapting amputee's gait [1] Prosthesis is an artificial device extension are generally used to replace parts lost by injury (traumatic) or missing from birth (congenital) or to supplement defective body parts. Prostheses are specifically not orthotics, although under given certain circumstances prosthesis might end up performing some or all of the same functionary benefits as an orthotics. Prostheses are technically the complete finished item. Prostheses are technically the complete finished item. For instance, a C-Leg knee alone is not prosthesis, but only a prosthetic component. The complete prosthesis would consist of the attachment system to the residual limb - usually a "socket", and all the attachment hardware components all the way down to and including the terminal device. [2]

Many researches were interested the design and manufacturing of prosthetics and orthotics: Muhsin J. Jweeg et al. use (perlon 6, 9 and 12 layers) [3]. Muhsin J. Jweeg and Jana S. Jaffar worked on perlon-carbon-perlon (424) and perlon only [4]. S. S. Hasan, et al. used different composite material for laminations [5]. Muhsin J. Jweeg et al. used different types of laminations [6].

A. A. Ibrahim studied the structural strength of the syme by using two laminate with various reinforcement [7]. Sam L. Philips and William Crelius begins with a data base on mechanical properties of lamination sockets, which subjected to tensile and bending tests. [8]. H. F. Neama, investigated stress distribution for below knee prosthetic socket. They worked on polypropylene and composite material sockets [9]. S. H. Mohammed presented numerically and experimentally studying for ankle-foot orthoses by using perlon and carbon fiber materials instead of polypropylene [10].

In the ever-changing field of orthotics and prosthetics, recent advancements have been achieved with the use of new materials and resins. In the spring of 1981, a study project was initiated in an attempt to learn the proper use of these hightech materials. Data was accumulated from various chemistry and physics texts on the characteristics of composite materials, specifically carbon, Kevlar, and fiberglass [11].Prostheses and Orthoses prescribed for partial foot amputations vary in design and principle [12]. The main goals of orthotic and prosthetic devices in partial foot amputations are to restore stability, maintain support, and protect the function of the residual 
limb. The materials and techniques used today have had significant positive effects on function and comfort of partial foot amputees [13].

In this work, tensile and fatigue test was applied for different samples of lamination from perlon, perlon with carbon fiber, perlon with fiber glass and perlon with n-glass in order to be used in manufacturing of prosthetic socket for partial foot to achieve the requirement of good socket design for acceptable mechanical properties and minimizing the cost.

\section{Experimental procedures}

\subsection{Materials}

The partial foot socket materials used in lamination for this study [14] as shown in Figure (1).

1. Perlon stockinet white.

2. Carbon fiber.

3. Fiber glass

4. Nyle glass.

5. Lamination resin 80:20.

6. Hardening powder.

7. Polyvinyalcohol PVA.

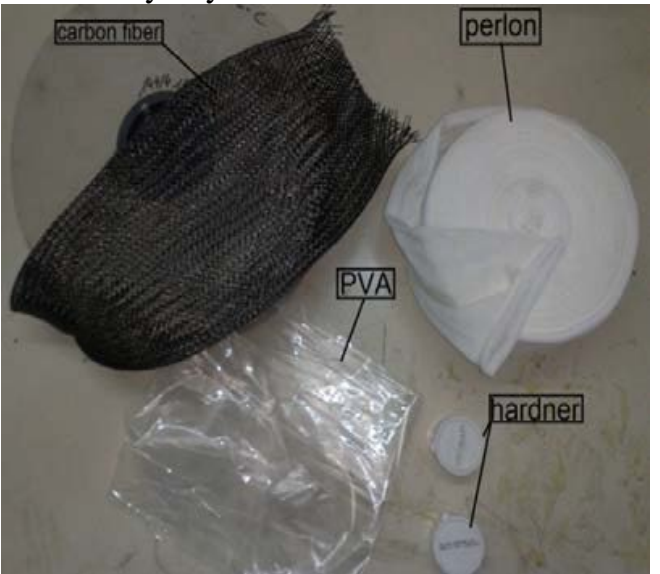

Figure 1: prosthetics and orthotics materials.

\subsection{Procedure of laminations}

a. Set the rectangular mold at the stand of vacuum pressure system as shown in Figure (2).

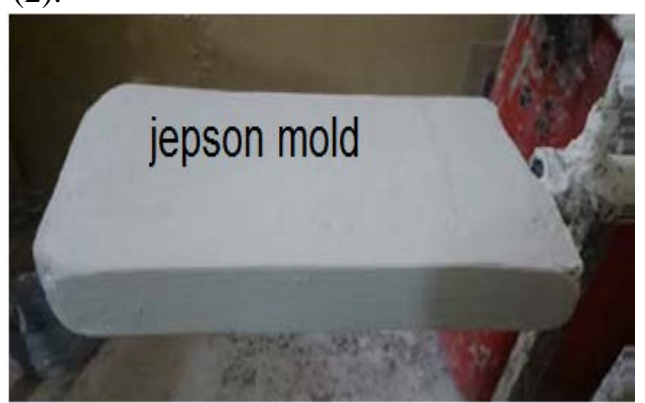

Figure 2: Positive mold.

b. Use the Perlon stockinet, Perlon and fiber glass stockinet and Perlon and carbon fiber stockinet Perlon and n- glass stockinet as indicated by the overlaying lay-up.

c. Blend the overlay resin 80:20 polyurethane with the hardener.

d. Maintain constant vacuum with pressure approximately $(30-60 \mathrm{KPa})$ at room temperature until the laminations becomes cold and cut according to the dimension of samples as shown in Figure (3).

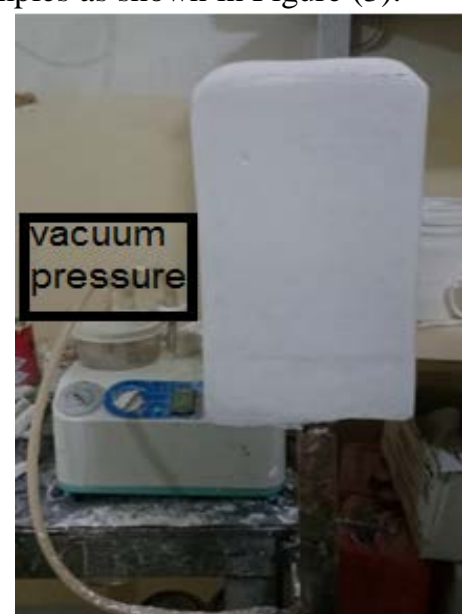

Figure 3: Positive mold with pressure system.

Universal instrument machine test (Testometric) for tensile as shown in Fig.(4). Three samples were prepared for each lamination according to ASTM D638 type I [15] while thickness varies according to the type of lay up. Fig.(5) shows the dimensions of tensile sample.

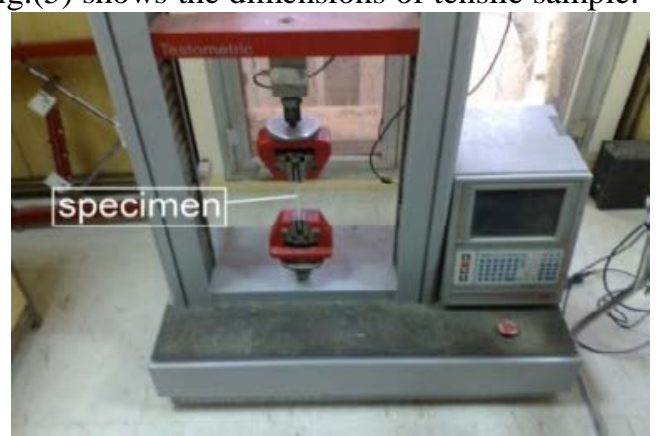

Figure 4: Tensile test device.
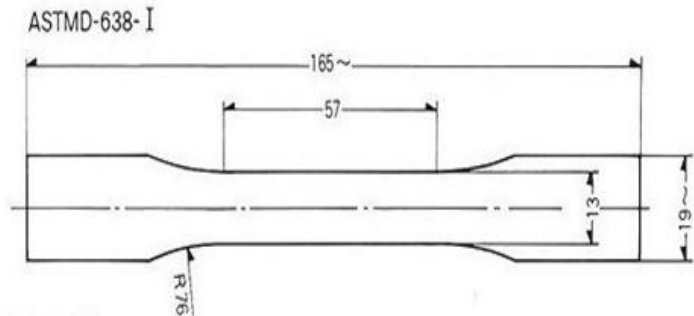

Figure 5: The dimensions of tensile specimen.

Material fatigue test for flat specimen as shown in Fig. 6 were characterized. Eight samples for each lamination used for fatigue test. The dimensions of samples has length of $100 \mathrm{~mm}$ and width $10 \mathrm{~mm}$ according to the fatigue device test 
while thickness various with the type of layup. Fig. (7) shows the shape of fatigue samples.

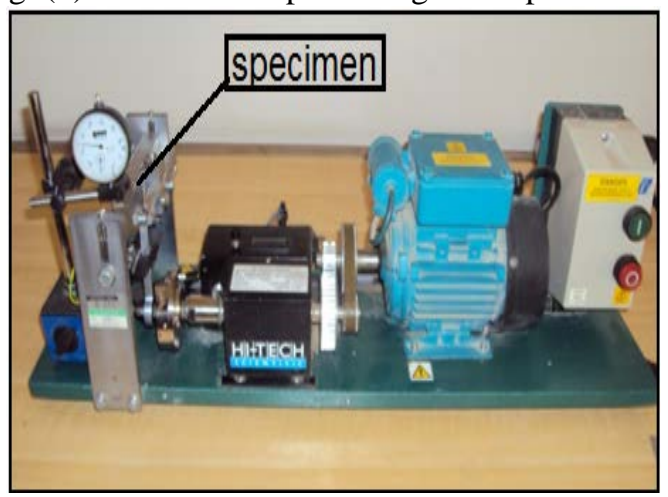

Figure 6: Fatigue test device.

d. $4 \mathrm{~mm}$

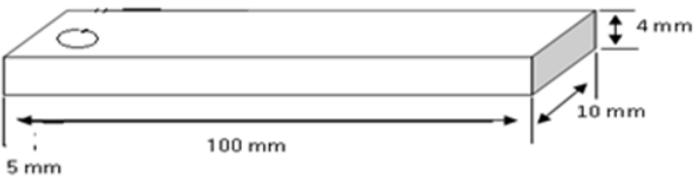

Figure 7: The shape of fatigue specimen.

The average thickness for the samples is measured and the laminations prepared are shown in Table 1.

Table 1: The lamination manufactured with different layup method

\begin{tabular}{|c|c|c|c|}
\hline No & $\begin{array}{l}\text { TotalNo } \\
\text { of layers }\end{array}$ & $\begin{array}{c}\text { Thickness } \\
(\mathrm{mm})\end{array}$ & Lamination lay up procedures \\
\hline Group $A$ & 7 & 3 & (3Perlon +1 carbon fiber +3 perlon) layers \\
\hline Group B & 7 & 3 & (3Perlon +1 fiberglass +3 perlon) layers \\
\hline Group C & 7 & 2.8 & $(3$ Perlon $+\ln$-glass +3 perlon)layers \\
\hline Group D & 8 & 3.5 & (3Perlon +2 carbon fiber +3 perlon)layers \\
\hline Group E & 8 & 3.7 & (3Perlon +2fiberglass +3perlon) layers \\
\hline Group F & 8 & 3.2 & $(3$ Perlon $+2 n$-glass +3 perlon)layers \\
\hline Group $\mathrm{G}$ & 4 & 1.9 & 4Perlon \\
\hline Group H & 6 & 2.5 & 6Perlon \\
\hline Group I & 8 & 2.9 & 8Perlon \\
\hline
\end{tabular}

\section{Results and discussions}

\subsection{Tensile properties results}

The results of each laminations sample are shown in Table (2) and from Figs.(8 to 13) which can be determined by taking the average value of mechanical properties.

1. For Perlon lamination the mechanical properties are increasing about (yield strength бy $70 \%$ and ultimate tensile strength oult $13 \%)$ with the increasing Perlon layers, but the mechanical properties(E) are decreasing about30\% with the increasing Perlon layers, especially for high number of Perlon layers because the matrix epoxy stronger than Perlon fiber these result agreement with.
2. For lamination (Perlon+fiberglass+Perlon) these properties results for increasing fiber glass with constant Perlon, are increasing about (yield strength $\sigma y 21 \%$, ultimate tensile strength oult 16\% and E 60\% ) for (Group B) as compared with( Group $\mathrm{H}$ ). and increasing about (yield strength oy $20 \%$, ultimate tensile strength oult 19\% and E 40\% ) for (Group E) as compared with (Group $\mathrm{H}$ ).

3. For lamination (Perlon+n-glass+Perlon) these properties results for increasing n-glass with constant Perlon, are decreasing yield strength бy $66 \%$ and increasing about (ultimate tensile strength oult about $0.9 \%$ and $\mathrm{E} 36 \%$ ) for (Group C) as compared with (Group H). and increasing about (yield strength oy 22\% , ultimate tensile strength oult 5.5\% and E 29\% ) for (Group F) as compared with (Group H). also the properties (yield strength oy73\%and ultimate tensile strength oult 5\%) are increasing with the increasing fiber glass layers these result agreement with [16].

4. For lamination (Perlon + carbonfiber + Perlon) these properties results for increasing carbon fiber with constant Perlon, are increasing about (yield strength oy $62 \%$, ultimate tensile strength oult $62 \%$ and E $68 \%$ ) for (Group A) as compared with (Group H). and increasing about (yield strength oy $71 \%$ ,ultimate tensile strength oult 76\% and E 58\% ) for (Group D) as compared with (Group H). also the properties (yield strength $\sigma y$ are increasing about 24\% and ultimate tensile strength oult are increasing about 38\%) with the increasing carbon fiber layers [16]. Due to increasing the ability of absorbing that can lead to increase in the thickness for each samples in plastic behavior for both materials. This addition of thickness come from the matrix material which was weaker than the fiber materials [17] This resulted in an optimum absorbing ability to the lamination 80:20can give higher mechanical properties for sandwich layup lamination.

Table 2: Mechanical properties evaluated from stress -strain curves.

\begin{tabular}{|c|c|c|c|c|c|}
\hline $\begin{array}{c}\text { No. of } \\
\text { Lam. }\end{array}$ & $\begin{array}{c}\text { Total } \\
\text { No } \\
\text { of } \\
\text { layers }\end{array}$ & $\begin{array}{c}\text { Thickness } \\
(\mathrm{mm})\end{array}$ & $\begin{array}{c}\boldsymbol{\sigma}_{\mathbf{y}} \\
\mathrm{MPa}\end{array}$ & $\begin{array}{c}\boldsymbol{\sigma}_{\text {ult }} \\
\mathrm{Mpa}\end{array}$ & $\begin{array}{c}\mathrm{E} \\
\mathrm{GPa}\end{array}$ \\
\hline Group A & 7 & 3 & 89.1 & 108.5 & 2.5 \\
\hline Group B & 7 & 3 & 42.5 & 48.6 & 2 \\
\hline Group C & 7 & 2.8 & 11.4 & 41.37 & 1.25 \\
\hline Group D & 8 & 3.5 & 117 & 175 & 1.9 \\
\hline Group E & 8 & 3.7 & 42 & 50.4 & 1.32 \\
\hline Group F & 8 & 3.2 & 43 & 43.4 & 1.13 \\
\hline Group G & 4 & 1.9 & 10.12 & 38.8 & 1.16 \\
\hline Group H & 6 & 2.5 & 33.6 & 41 & 0.8 \\
\hline Group I & 8 & 2.9 & 34.45 & 44.4 & 1.01 \\
\hline
\end{tabular}




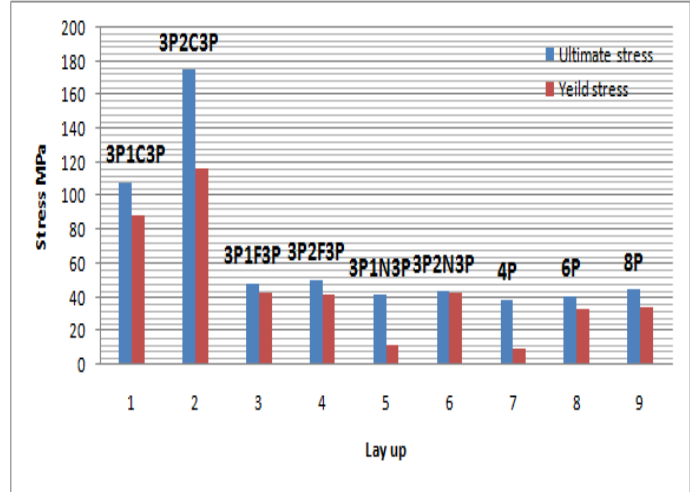

Figure 8: Variation of ultimate and yield stress with laminations.

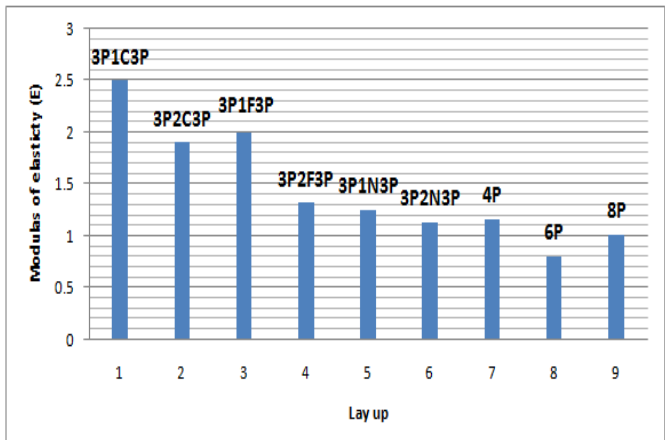

Figure 9: Variation modulus of elasticity with laminations.

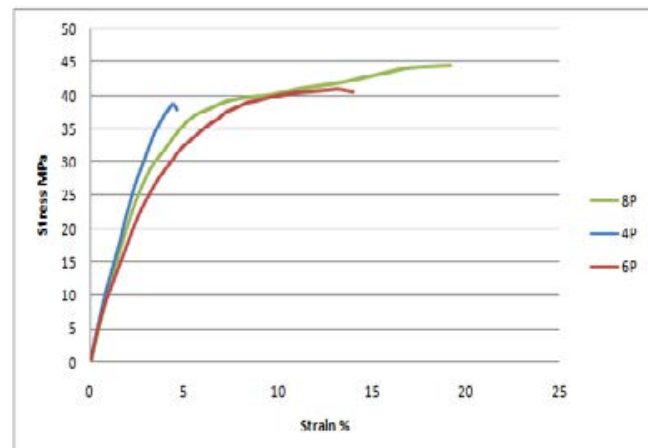

Figure 10: Stress-strain curve for one sample of each perlon lamination.

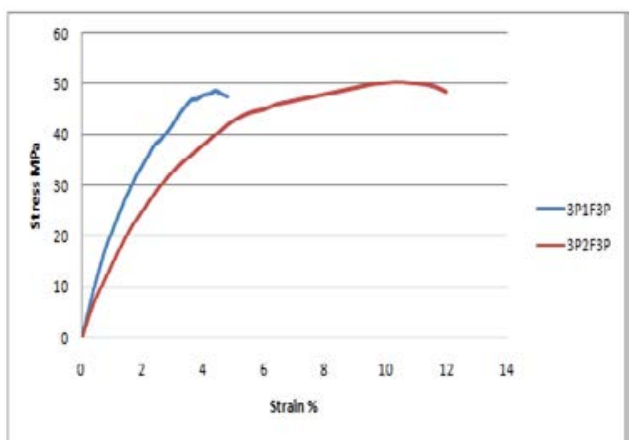

Figure 11: Stress-strain curve for one sample of each perlon fiber glass perlon lamination

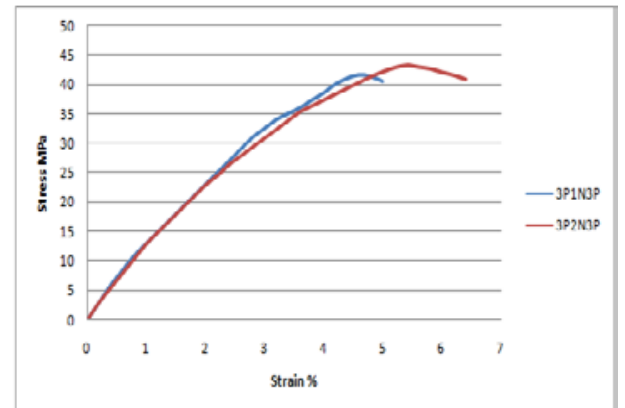

Figure 12: Stress-strain curve for one sample of each perlon n-glass perlon lamination

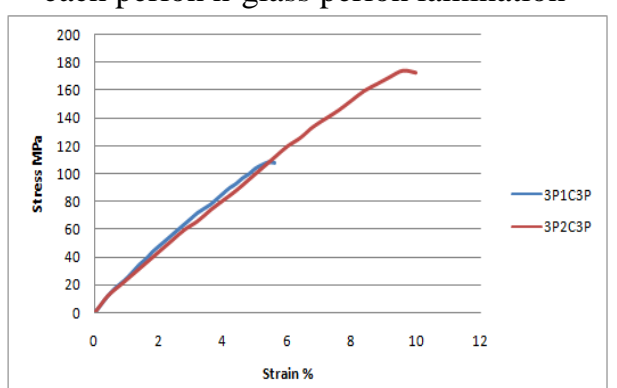

Figure 13: Stress-strain curve for one sample of each perlon carbon fiber perlon lamination

Also, it can be noticed that lamination which consisted of three layers of Perlon plus two layers of carbon fiber plus three layers of Perlon bound by the lamination (80:20) resin matrix, had the best mechanical properties.

\subsection{Fatigue properties results}

The failure of fatigue of flat specimen can be occur when the specimen fractures under alternating bending with high cycle fatigue. The readings were recorded by the fatigue tester machine give the number of cycles when the specimens were fractured. The $\mathrm{S}-\mathrm{N}$ curves for each samples of all laminations as shown in Figures from Figure (14). to Figure (18).

The failure stresses are decreasing and the number of cycles to reach to the failure is increasing at constant temperature.

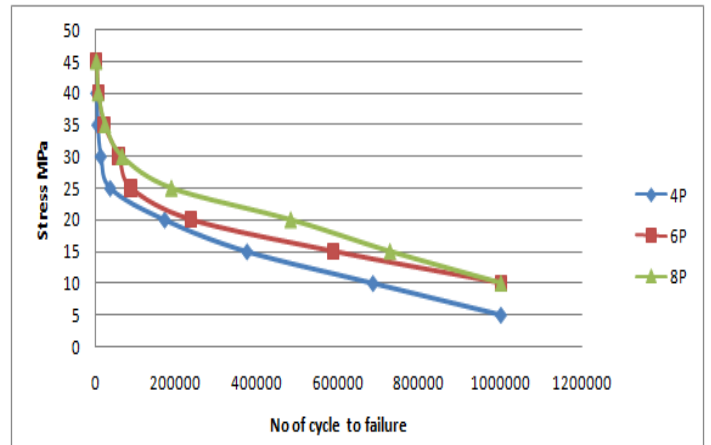

Figure 14: S-N curves for perlon laminations. 


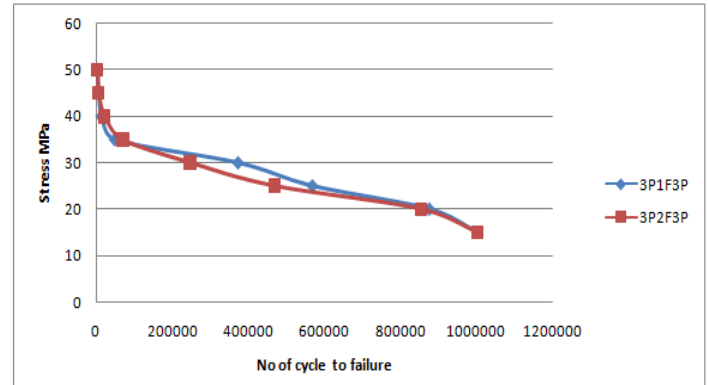

Figure 15: S-N curves for perlon fiber glass perlon laminations.

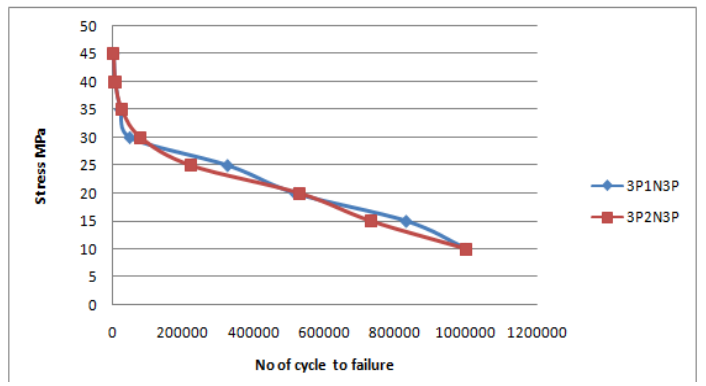

Figure 16: S-N curves for perlon n- glass perlon laminations.

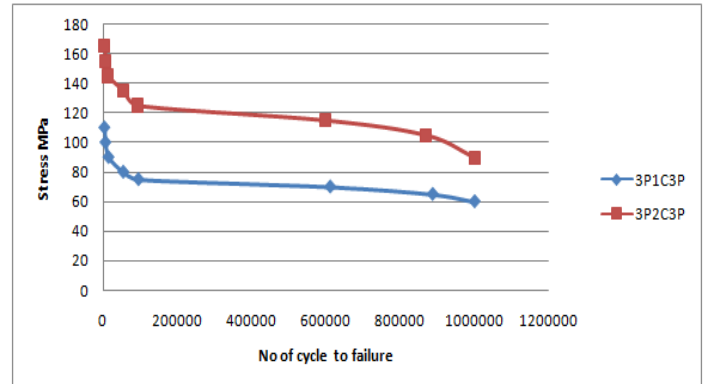

Figure 17: S-N curves for perlperlon laminations.

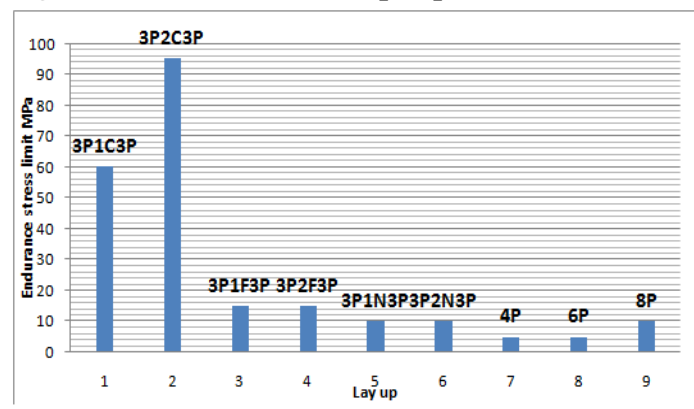

Figure 18: Fatigue endurance stress limit with various laminations.

\section{Conclusions}

This study gives a good database for manufacturing suitable lamination of partial foot prosthetic socket for patients with below ankle amputee. The conclusions of this work are as follows:

1. The lamination which consists of $(3 \mathrm{P}+2 \mathrm{C}+3 \mathrm{P})$ are considered the best lamination lay up. It is recommend to use this type of lamination for the layup partial foot prosthetic socket because it meets the demand lamination layers of socket for acceptable mechanical properties and its minimizing the cost of socket lamination to suitable costing value.

2. For constant layers of perlon the mechanical properties are improved when increasing of carbon fiber, fiber glass and n-glass layers. Using two layers of carbon fiber instead of zero layer with six layers of perlon lead to the increased in(yield strength $\sigma y$, ultimate tensile strength oult and modules of elasticity E with (51\%,75\% and 58\%) respectively for carbon fiber, (20\% , 19\% and 40\%) for fiber glass and ( $22 \%, 5.5 \%$ and $29 \%$ ) for n-glass.

3. The lifetime for prosthesis depends on the applied stress and the composite material type. The lamination which consists of (3perlon+2carbon fiber+3 perlon) has Endurance limit stresses ( $\sigma \mathrm{e})$ is much longer than the other laminations. This increase in lifetime for the patient wearing partial foot prosthetic.

\section{References}

1. B. L. Klasson, "Carbon fiber and fibril lamination in prosthetics and orthotics: some basic theory and practical advice for the practitioner ", Prosthetics and Orthotics International, Vol. 19, 1995, 74-91.

2. Popovic D., and Sinkjaer T. (2000), “Control of movement for the physically disabled” , Springer-Verlag London.

3. Muhsin J.Jweeg, Kadhim K. Resan and Muhanad N. Mohammed," Design and Manufacturing of a New Prosthetic Low Cost Pylon for Amputee”. Journal of Engineering and Development, Vol. 14, No. 4, 2010

4. Muhsin J.Jweeg and Jana S. Jaffar,” Vibration Analysis of Prosthesis for the through Knee Amputation”. Al-Nahrain University, College of Engineering Journal (NUCEJ) Vol.91 No.1, 2016 pp.46 - 55,2013.

5. Muhsin J. Jweeg, S.S.Hasan, and J.S.Chiad,” Effects of Lamination Layers on the Mechanical Properties for above Knee Prosthetic Socket”. Eng. \&Tech.Journal, Vol.27, No.4, 2009.

6. Muhsin J. Jweeg, Ayad M. Takhakh, and Saif M. Abbas "Characterization of materials used in manufacturing the ankle foot ortheses ", International Journal of Energy and Environment Issue on Applied Mechanics Research" Volume 8, Issue 4, 2017 pp.291298, 2017

7. Ahmed Aladdin Ibrahim, "Development and Testing of Syme Prostheses with Enhanced Structural Strength", PhD Dissertation, Mechanical Eng. Dept., University of Technology, Baghdad, Iraq, (2000).

8. Sam L.Philips and William Craelius,"Material Properties of Selected Prosthetic Laminates", 
Journal of Prosthesis and Orthotics, Vol.17, No.1, (2005).

9. Samira K.Radi, Haider F. Neama: "Analysis of a Below Knee Prosthetic Socket ", J. Eng. and development vol.12, No.2, pp.127-135, June (2008).

10. Samir Hashim Ameen, "Numerical and Experimental Investigation of Ankle-Foot Orthoses using (Perlon-Carbon FibersAcrylic) Materials", PhD dissertation, College of Engineering of Nahrain University, Baghdad, Iraq, (2011).

11. Dale A. Berry, C.P. "Composite Materials for Orthotics and Prosthetics" Orthotics and Prosthetics vol.40, No.4, pp.35-43, 1987.

12. Melvin L. Stills, C O., "Partial Foot Prostheses/Orthoses" clinical Orthotics and Prosthetic vol.12, No.1, pp.14-18, 1988.
13. Terrence M. Philbin, DO, Manuel Leyes, MD, James J. Sferra, MD, and Brian G. Donley, MD, “Orthotic and Prosthetic Devices in Partial Foot Amputations”,2001.

14. Ottobock quality for life "orthoticprosthetic materials catalog", 2007.

15. American society for testing and materials information ,Handing series "standard test method for Tensile properties" 2000.

16. Jumaa S. C. Adawiya A. H. 2014. Experimental Study for Materials Prosthetic above Knee Socket under Tensile or Fatigue Stress with Varying Temperatures Effect. Number 3 - March Volume 202014 Journal of Engineering.

17. J. N. Reddy. 2005. Mechanics of laminated composite plates and shells.Third edition, Crcpress.

\title{
تأثير طبقات المواد المركبة على الخواص الميكانيكية لوقب طرف صناعي خلال القدم
}

\author{
قنم هندسة الأطر اف وحمد عباس المساند الصناعية \\ جامعة النهرين- بغداد - العراق
}

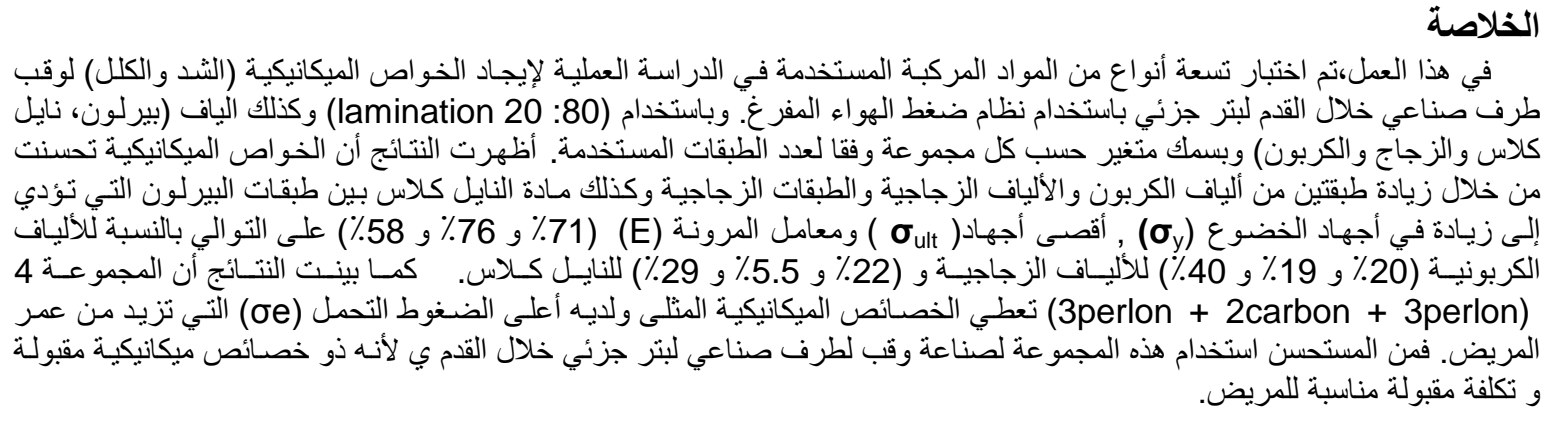

